\title{
DRILLABILITY PREDICTION USING REGRESSION ANALYSIS FOR SOME EGYPTIAN ROCKS
}

\author{
Mahrous A. M. Ali ${ }^{1}$, WaelAbdellah ${ }^{2}$, A. K. Abd El Aal ${ }^{3}$ \\ ${ }^{I}$ Mining and Petroleum Department Faculty of Engineering, Al-Azhar University, Qena, Egypt \\ ${ }^{2}$ Mining and Metallurgical Department Faculty of Engineering, Assiut University, Assiut, Egypt \\ ${ }^{3}$ Geology Department Faculty of Science, Al-Azhar University, Assiut, Egypt, Civil Engineering Department., Faculty \\ of Engineering, Najran University, P.O. Box 1988, Najran, Saudi Arabia
}

\begin{abstract}
Drilling and blasting operation are an essential and integral part of mining cycle/process. They are almost employed in all mining methods (e.g., surface and underground works) as well some civil engineering projects (e.g., dams, roads construction and tunnel excavation). In feasibility studies (e.g., planning and preliminary cost estimation), the rock penetration rate (e.g., drillability) is used as a tool to predict the rock mass strength properties/characteristics. This paper examines the relationship between strength properties of selected rocks in Egypt and their drillability. Six natural rock types; were selected from different locations in the country, and another five artificial rocks; prepared in the lab with different composition, were tested in the laboratory for uniaxial compressive strength, tensile strength, shear strength, hardness (e.g., point load strength and impact strength) and rate of penetration. The regression equation is then established from the relationship between strength properties of rock and the penetration rate. The results revealed that strong correlation exists between penetration rate and compressive and tensile strength with correlation coefficient of $R^{2} \geq 0.75$ for both exponential and logarithmic functions. For Barazilian tensile strength, the correlation coefficient was of $R^{2} \geq 0.7$. The relationship between specific energy (SE) and rock strength properties are also presented and discussed in this study, where the results showed strong correlation.
\end{abstract}

Keywords: Drillability, Rock Strength Properties, Specific Energy (SE), Regression Analysis.

$* * *$

\section{INTRODUCTION}

Efficient planning of mining projects (e.g., rock excavation) depends essentially on accurate estimation of the rate of penetration. Rock penetration rate (e.g., drillability) is mainly influenced by controllable and uncontrollable parameters. The drilling speed (RPM), thrust (WOB), flushing and fluid properties are controllable/operational variables, whilst, rock properties and geological conditions are uncontrollable parameters (Kahraman et al., 2003). Many researchers/authors examined the relationship between the different rock characteristics and their penetration rates. Paone and others reported in their study, (Paone et al., 1969) that, penetration rates do not significantly change for rocks that having a compressive strength greater than $173 \mathrm{MPa}$. The relationship between rate of penetration, thrust (WOB) and uniaxial compressive strength of rock $\left(\sigma_{c}\right)$ was studied by Fish (Fish, 1968). It is found that, the rate of penetration is directly proportional with WOB and inversely proportional with $\left(\sigma_{c}\right)$. A regression models proposed by Karpuz (Karpuz et al., 1990) to predict the penetration rate of rotary tri-cone and drag bits. The study revealed that uniaxial compressive strength $\left(\sigma_{c}\right)$ is considered as a dominant/major rock property. The rock drillability index (RDi) was defined by Morris (Morris, 1969) as the ratio of crater depth- to- threshold force. Tungsten carbide bits were used during measuring the rate of penetration.
The correlation between drilling efficiency, rock hardness, drilling strength and triaxial strength was investigated by Clark (Clark, 1979). According to study done by Paone (Paone et al., 1966), the major important factors are influencing the rate of penetration were weight on bit or thrust (WOB), drilling speed (RPM) and rock strength properties (e.g., $\sigma_{c}$, hardness, mineral content ). A new model for penetration rate was developed by Warren (Warren, 1981) and applied to rotary tri-cone bits in soft formations. That model correlates the relationship between WOB, RPM, bit geometry (e.g., size and type) and rock strength properties to the rate of penetration.

A new portable rock strength index test was established; by Teale (Teale, 1964), Reddish and Yasar (Reddish and Yasar, 1996), based on specific energy (SE) of rotary drilling. Kahraman (Kahraman, 1999) studied the regression analysis and developed models of penetration rate for rotary drills (e.g., down-the-hole hammers and hydraulic top hammer). A new drillability index was obtained from forcepenetration curves of indentation tests (Kahraman et al., 2000). Consequently, it was adopted to develop a mathematical penetration rate model for rotary drills. Pandey (Pandey et al., 1991) established the logarithmic relationships between micro-bit drilling test and mechanical properties of rock beside Protodyakonov index. Kahraman (Kahraman, 2002) statistically investigated the relationships between three different methods of brittleness and both 
drillability and bore ability using the raw data obtained from the experimental works of different researchers. Adamson (Adamson, 1984) illustrated a correlation between a quantitative measure of rock texture, the texture coefficient, and penetration rate of rotary drill. The locations of the collected stones for this study are depicted in Figure (1) below. The tested rock samples; natural and artificial, and their composition are listed in Table (1) below.

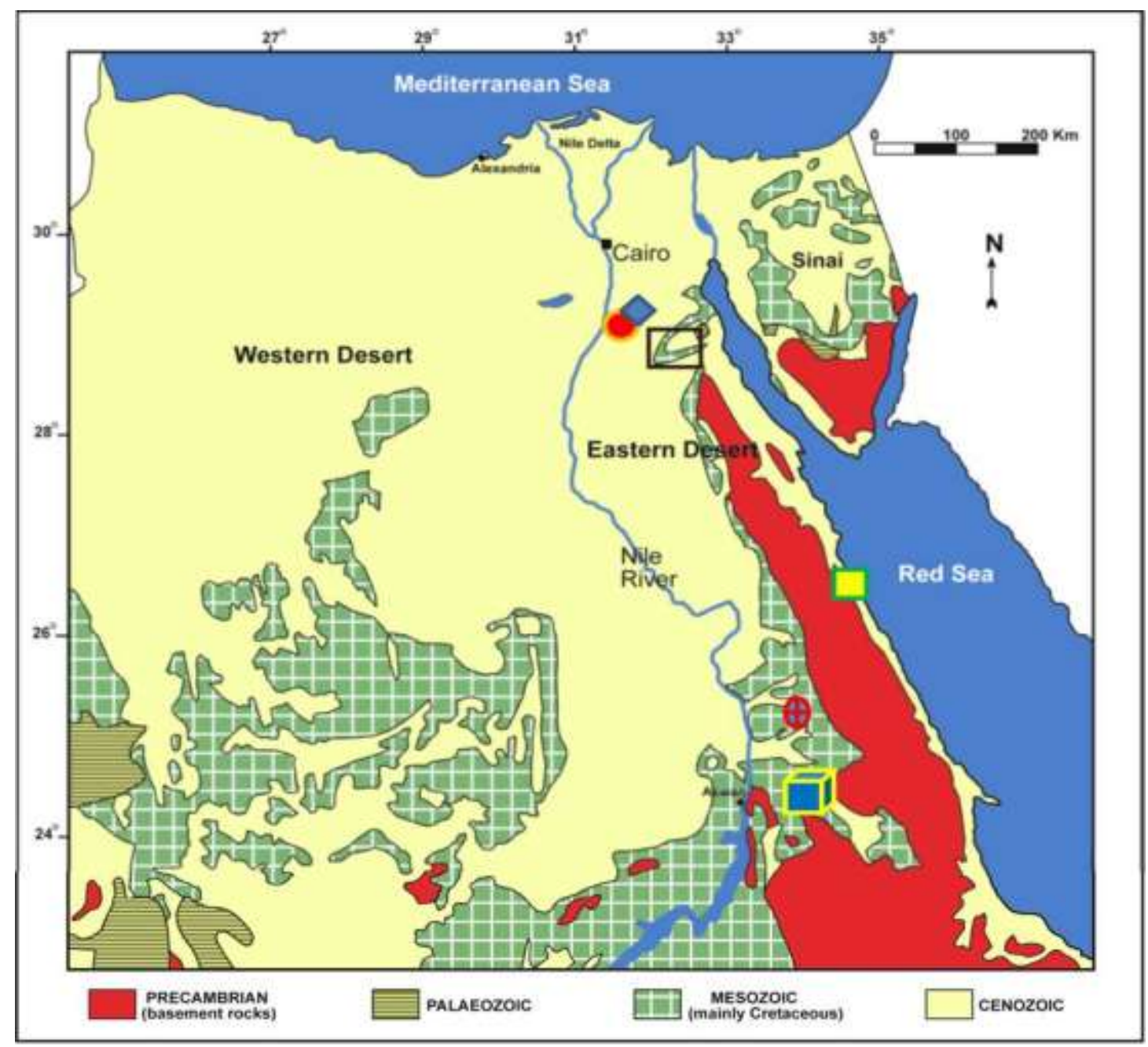

\section{Limestone \\ Marble \\ Dolomite \\ Basalt}

Fig 1: Geological map of Egypt shows the location of selected rocks for study (modified after CONOCO, 1987).

Table1: Naturalrock types and artificialcomposition

\begin{tabular}{|c|c|c|c|}
\hline Rock type & \multicolumn{2}{|c|}{ Composition } & sample no. \\
\hline \multirow{5}{*}{ Natural } & \multirow{5}{*}{\multicolumn{2}{|c|}{$\begin{array}{ll}1- & \text { Limestone } \\
\text { 2- } & \text { Sandstone } \\
\text { 3- } & \text { Dolomite } \\
\text { 4- } & \text { Marble } \\
5- & \text { Basalt } \\
\end{array}$}} & 7 \\
\hline & & & 5 \\
\hline & & & 6 \\
\hline & & & 5 \\
\hline & & & 7 \\
\hline \multirow{5}{*}{$\begin{array}{l}\text { Artificial } \\
\text { (by weight \%) }\end{array}$} & & \multirow{5}{*}{$\begin{array}{l}50 \% \text { Cement }+50 \% \text { Sand } \\
25 \% \text { Limestone }+25 \% \text { Dolom }+50 \% \text { Cement } \& \text { Sand } \\
25 \% \text { Dolomite }+25 \% \text { Basalt }+50 \% \text { Cement } \& \text { Sand } \\
25 \% \text { Limestone }+25 \% \text { Basalt }+50 \% \text { Cement } \& \text { Sand } \\
20 \% \text { Limestone }+20 \% \text { Dolomite }+20 \% \text { Basalt }+40 \% \text { Cement } \& \text { Sand }\end{array}$} & 5 \\
\hline & & & 6 \\
\hline & & & 6 \\
\hline & & & 5 \\
\hline & & & 5 \\
\hline
\end{tabular}




\section{SAMPLE PREPARATION}

For natural rock samples about 30 were prepared from all rock type in accordance with the standards suggested by the International Society of Rock Mechanics (ISRM 1981) and the American Society forTesting and Materials International (ASTM2001).. Thus, for uniaxial compressive strength test, core samples of $50 \mathrm{~mm}$ diameter and length to diameter $(L / d=2.0)$ ratio of two times were prepared (Fig. 2 a, b, c, $\mathrm{d}$, e and $\mathrm{f}$ ). While, core samples of $50 \mathrm{~mm}$ diameter and length to diameter $(L / d=1.0)$ ratio of unity were prepared for Brazilian tensile test. The artificial stones were prepared as shown in table 2, they are about 27 samples, Slabs of rectangular cross-section of $10 \times 20$-mm and100-mm long were prepared for shear strength test (Fig $3 \mathrm{a}, \mathrm{b}, \mathrm{c}, \mathrm{d}, \mathrm{e}, \mathrm{f}, \mathrm{g}$, $\mathrm{h}$ and $\mathrm{j}$ ). Point load test was carried out on the cones having a diameter $50-\mathrm{mm}$ and a length of $100-\mathrm{mm}$ and on the rectangular samples having a thickness of 50-mm. The Impact strength test was used the device of impact test where a $100 \mathrm{gm}$. sample of rock (e.g., ranges from 3-mm to 9-mm) is placed inside a cylinder (e.g., 42-mm diameter).

\section{EXPERIMENTAL WORK}

This study aims to estimate the mechanical properties of natural and artificial stones which are correlated with their drillability. The experimental work includes the determination of mechanical rock properties and the relation between these properties and the penetration rate of the rock .Mechanical tests include uniaxial compressive strength $\left(\sigma_{c}\right)$; at an increasing loads from 0.5 to $1 \mathrm{MPa} / \mathrm{s}$., Barazilian tensile strength $\left(T_{S}\right)$ (e.g., increasing loads until failure occurs), shear strength $\left(\sigma_{\tau}\right)$ point load strength (PLT) and impact strength (I.S.) (e.g., where a $19 \mathrm{~kg}$ weight is dropped 25-times from a height of $30.5-\mathrm{cm}$ on to the rock sample). The penetration rates (drillability) were determined by core retrieval drilling machine. Then the relationships between mechanical properties of natural and artificial stones and their penetration rates were examined and interpreted. It is worthy to mention that the operating parameters (e.g., bit type, WOB, RPM, etc.) of rotary drilling machine were kept constant during the experimental work. Table (2 and 3)gives the rates of penetration for the different natural and artificial stones and their mechanical strength.
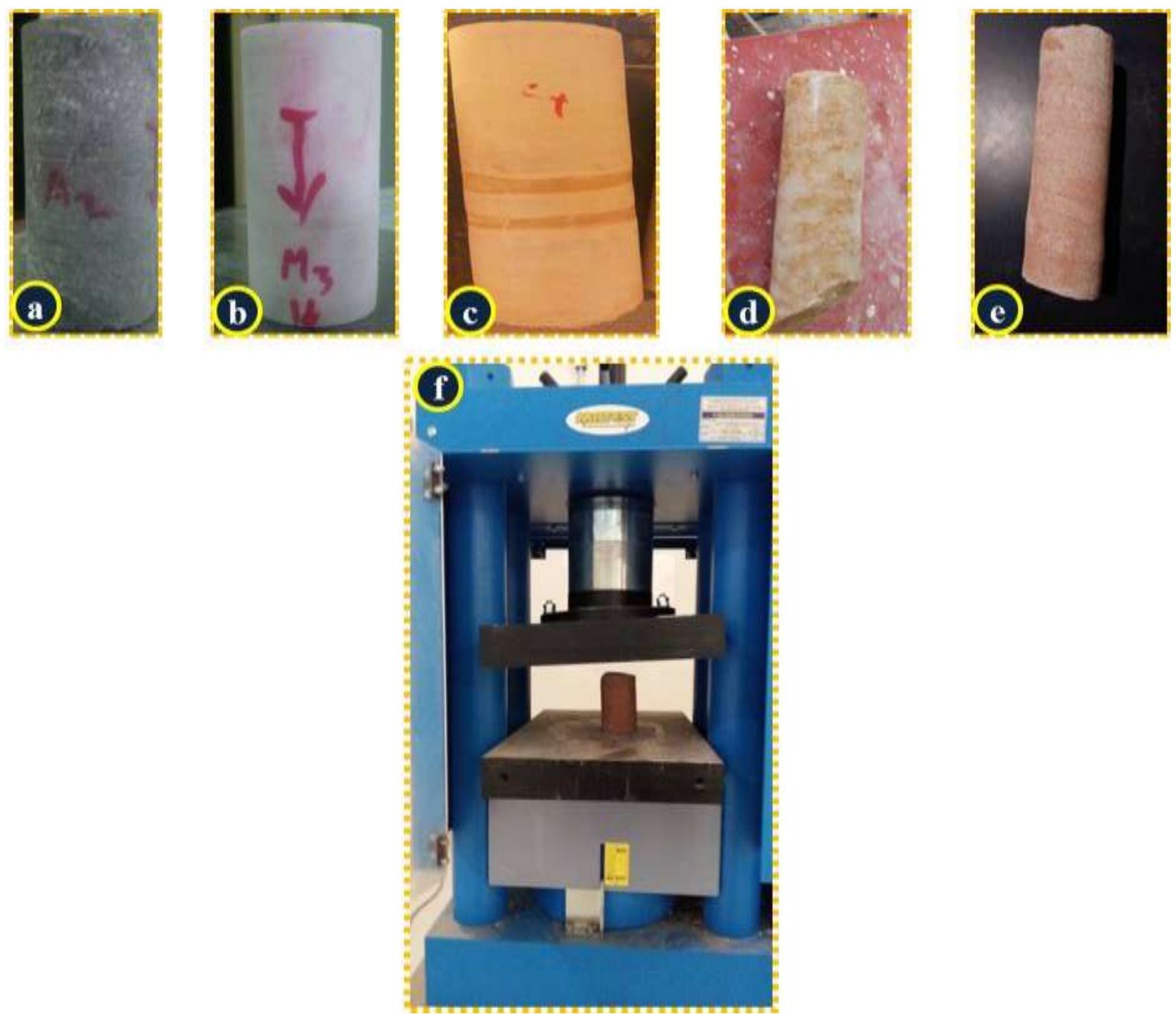

Fig 2 (a, b, c, d, e and f): preparation of core samples of rock and $\mathrm{f}, \mathrm{s}$ the uniaxial compression strength machine 

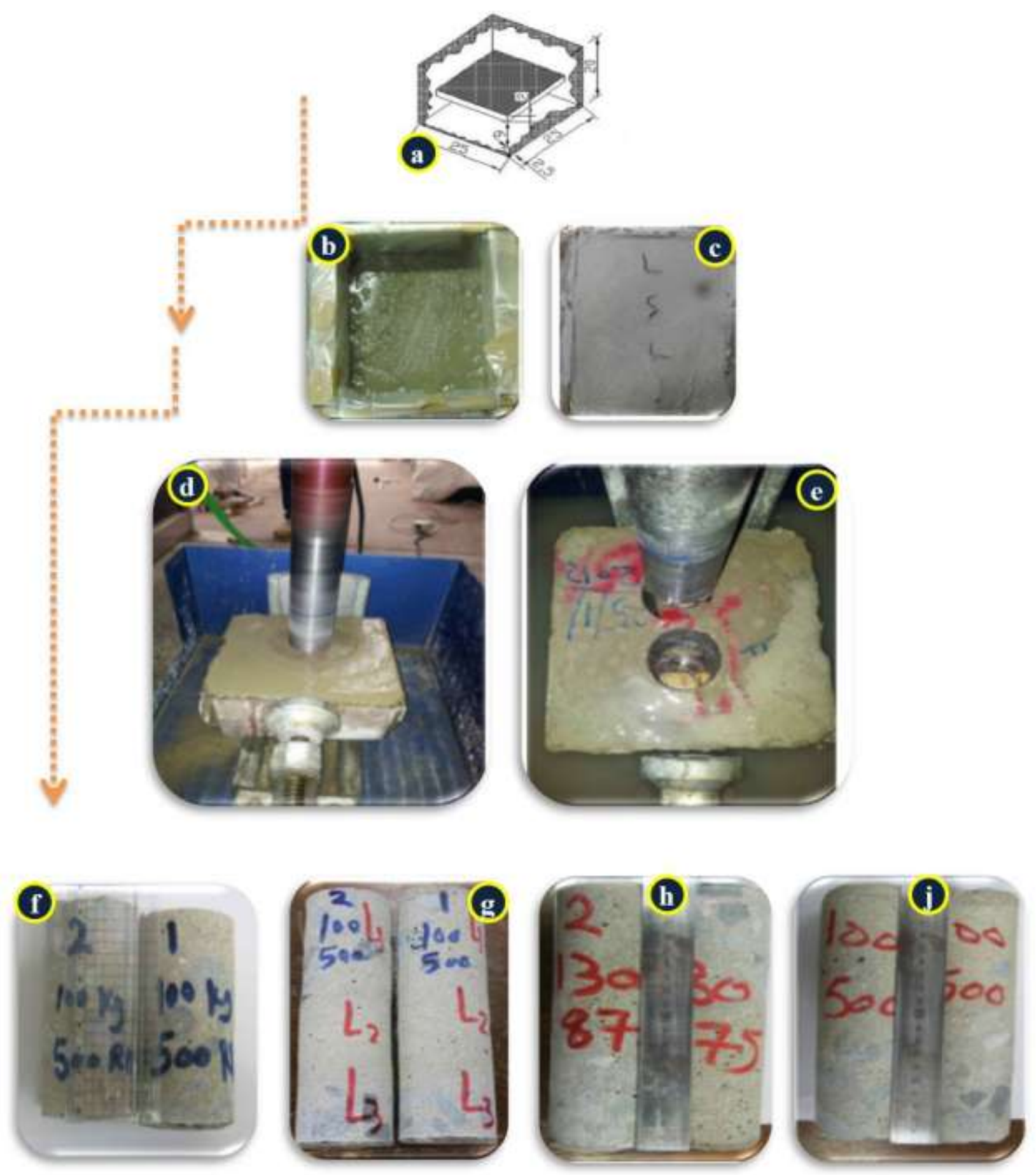

Fig 3: a, model used in the present work, band c, casting the samples, d\&e coring the artificial sample, $f, g, h$, and $j$ are the core samples after cutting by coring machine 
Table 2: Rates of penetration and mechanical characterization of natural rocks

\begin{tabular}{|c|c|c|c|c|c|c|c|}
\hline Rock name & Sample No. & $\mathrm{P}, \mathrm{mm} / \mathrm{min}$ & $\begin{array}{l}\sigma_{\mathrm{c}} \\
\mathrm{MPa}\end{array}$ & $\begin{array}{l}\sigma_{\mathrm{t}} \\
\mathrm{MPa}\end{array}$ & $\begin{array}{l}\text { Ts, } \\
\text { MPa }\end{array}$ & PLS, MPa & $\begin{array}{l}\mathrm{I} . \mathrm{S} \\
\%\end{array}$ \\
\hline \multirow{7}{*}{ Limestone } & 1 & 13.25 & 68.52 & 8.21 & 14.56 & 41.14 & 71.25 \\
\hline & 2 & 12.45 & 69.36 & 8.33 & 15.23 & 42.01 & 73.45 \\
\hline & 3 & 13.44 & 68.32 & 8.01 & 14.23 & 42.43 & 71.24 \\
\hline & 4 & 12.67 & 69.11 & 7.08 & 15.02 & 42.61 & 71.33 \\
\hline & 5 & 13.76 & 67.91 & 8.65 & 14.33 & 41.57 & 70.23 \\
\hline & 6 & 13.41 & 67.53 & 8.45 & 14.55 & 41.33 & 69.19 \\
\hline & 7 & 13.81 & 68.88 & 8.72 & 14.03 & 39.88 & 72.05 \\
\hline \multirow{5}{*}{ Sandstone } & 8 & 35.65 & 55.25 & 7.85 & 13.22 & 31.22 & 60.58 \\
\hline & 9 & 37.05 & 55.02 & 7.65 & 13.66 & 30.11 & 60.12 \\
\hline & 10 & 34.65 & 53.54 & 7.89 & 12.65 & 29.76 & 61.02 \\
\hline & 11 & 35.69 & 53.65 & 8.22 & 11.54 & 29.23 & 60.55 \\
\hline & 12 & 36.28 & 55.33 & 7.66 & 13.2 & 30.41 & 60.62 \\
\hline \multirow{6}{*}{ Dolomite } & 13 & 2.55 & 90.54 & 9.88 & 21.55 & 51.72 & 89.75 \\
\hline & 14 & 2.33 & 91.32 & 9.88 & 20.1 & 50.41 & 89.75 \\
\hline & 15 & 2.36 & 91.12 & 9.88 & 19.23 & 51.27 & 89.75 \\
\hline & 16 & 2.37 & 91.9 & 9.88 & 18.51 & 50.4 & 89.75 \\
\hline & 17 & 3.31 & 90.65 & 9.88 & 19.29 & 49.61 & 89.75 \\
\hline & 18 & 2.98 & 90.1 & 9.88 & 20.87 & 48.77 & 89.75 \\
\hline \multirow{5}{*}{ Marble } & 19 & 2.87 & 77.29 & 8.55 & 18.75 & 36.65 & 61.85 \\
\hline & 20 & 4.99 & 75.65 & 7.65 & 18.98 & 38.52 & 67.55 \\
\hline & 21 & 2.43 & 74.23 & 8 & 18.75 & 37.43 & 65.05 \\
\hline & 22 & 4.76 & 76.76 & 7.98 & 18.98 & 36.43 & 64.55 \\
\hline & 23 & 3.56 & 75.43 & 8.12 & 18.75 & 35.79 & 64.49 \\
\hline \multirow{7}{*}{ Basalt } & 24 & 20.3 & 112.45 & 13.22 & 30.22 & 67.55 & 91.24 \\
\hline & 25 & 1.65 & 120.33 & 13.45 & 31.09 & 69.45 & 93.03 \\
\hline & 26 & 1.25 & 110.35 & 12.87 & 30.27 & 65.12 & 89.04 \\
\hline & 27 & 1.89 & 109.12 & 14.33 & 29.46 & 66.34 & 90.31 \\
\hline & 28 & 1.99 & 116.22 & 12.98 & 29.51 & 65.08 & 91.33 \\
\hline & 29 & 2.3 & 114.33 & 13 & 31 & 67.09 & 92.7 \\
\hline & 30 & 1.44 & 104.36 & 12.69 & 29.96 & 66.22 & 91.01 \\
\hline
\end{tabular}

Table 3: Rates of penetration and mechanical characterization of Artificial rocks

\begin{tabular}{|l|l|l|l|l|l|l|l|}
\hline \multirow{2}{*}{ Rock name } & Sample No. & $\mathrm{P}, \mathrm{mm} / \mathrm{min}$ & $\begin{array}{l}\sigma_{\mathrm{c}}, \\
\mathrm{MPa}\end{array}$ & $\begin{array}{l}\sigma_{\mathrm{t}}, \\
\mathrm{MPa}\end{array}$ & $\begin{array}{l}\text { Ts, } \\
\text { MPa }\end{array}$ & PLS, MPa & $\begin{array}{l}\text { I.S } \\
\%\end{array}$ \\
\hline \multirow{5}{*}{ Cement+Sand } & $\mathbf{3}$ & $\mathbf{3 3 . 2 5}$ & $\mathbf{1 6 . 7 7}$ & $\mathbf{2 . 2 1}$ & $\mathbf{3 . 5 8}$ & $\mathbf{1 0 . 2 2}$ & $\mathbf{3 7 . 3 2}$ \\
\cline { 2 - 8 } & $\mathbf{2}$ & $\mathbf{3 3 . 1 8}$ & $\mathbf{1 7 . 2 9}$ & $\mathbf{1 . 9 9}$ & $\mathbf{3 . 8 7}$ & $\mathbf{9 . 6 5}$ & $\mathbf{3 7 . 1 3}$ \\
\cline { 2 - 8 } & $\mathbf{3}$ & $\mathbf{3 3 . 8 5}$ & $\mathbf{1 6 . 8 8}$ & $\mathbf{1 . 6 5}$ & $\mathbf{3 . 3 4}$ & $\mathbf{9 . 8 9}$ & $\mathbf{3 7 . 3 5}$ \\
\cline { 2 - 8 } & 4 & $\mathbf{3 3 . 1 5}$ & $\mathbf{1 7 . 2 3}$ & $\mathbf{2 . 1 1}$ & $\mathbf{3 . 9 9}$ & $\mathbf{9 . 3 9}$ & $\mathbf{3 6 . 4 7}$ \\
\cline { 2 - 8 } & $\mathbf{5}$ & $\mathbf{3 2 . 8 9}$ & $\mathbf{1 6 . 2}$ & $\mathbf{2}$ & $\mathbf{3 . 9 7}$ & $\mathbf{1 0 . 2}$ & $\mathbf{3 8 . 3 3}$ \\
\hline \multirow{3}{*}{$\begin{array}{l}\text { Lime } \\
\text { Dolomite }\end{array}$} & $\mathbf{6}$ & $\mathbf{2 9 . 3 2}$ & $\mathbf{2 0 . 6 6}$ & $\mathbf{1 . 9 9}$ & $\mathbf{4 . 3 3}$ & $\mathbf{1 2 . 5 4}$ & $\mathbf{4 4 . 5 6}$ \\
\cline { 2 - 8 } & $\mathbf{7}$ & $\mathbf{2 9 . 2 3}$ & $\mathbf{2 1 . 1 8}$ & $\mathbf{1 . 6 5}$ & $\mathbf{4 . 2 1}$ & $\mathbf{1 2 . 6 3}$ & $\mathbf{4 5 . 0 1}$ \\
\hline
\end{tabular}




\begin{tabular}{|c|c|c|c|c|c|c|c|}
\hline & 8 & 28.44 & 20.46 & 2.01 & 4.34 & 12.12 & 46.15 \\
\hline & 9 & 28.66 & 19.99 & 1.7 & 4.96 & 13.25 & 43.45 \\
\hline & 10 & 28.75 & 19.48 & 1.88 & 3.55 & 12.13 & 44.33 \\
\hline & 11 & 29.56 & 21.03 & 1.98 & 3.87 & 12.54 & 43.88 \\
\hline \multirow{6}{*}{$\begin{array}{l}\text { Dolomite } \\
\text { Basalt }\end{array}$} & 12 & 26.45 & 25.17 & 3.01 & 6.98 & 16.33 & 47.32 \\
\hline & 13 & 26.02 & 24.76 & 2.44 & 6.74 & 15.8 & 47.85 \\
\hline & 14 & 26.99 & 24.65 & 2.22 & 6.54 & 15.44 & 46.54 \\
\hline & 15 & 26.21 & 24.1 & 1.98 & 6.33 & 16.58 & 46.68 \\
\hline & 16 & 26.11 & 23.54 & 2.99 & 5.88 & 13.43 & 48.52 \\
\hline & 17 & 26.89 & 23.9 & 3.6 & 6.89 & 14.33 & 46.98 \\
\hline \multirow{5}{*}{ Basalt + Lime } & 18 & 21.78 & 15.2 & 2.63 & 6.21 & 13.2 & 42.54 \\
\hline & 19 & 18.88 & 12.67 & 2.98 & 6.14 & 11.31 & 42.31 \\
\hline & 20 & 21.21 & 13.02 & 2.54 & 6.17 & 11.05 & 42.4 \\
\hline & 21 & 19.44 & 14.05 & 2.34 & 5.77 & 11.1 & 43.33 \\
\hline & 22 & 21.44 & 13.33 & 2.78 & 6.75 & 10.76 & 42.12 \\
\hline \multirow{5}{*}{$\begin{array}{l}\text { Lime } \\
\text { Dolom } \\
\text { Basalt }\end{array}$} & 23 & 21.33 & 18.32 & 2.49 & 6.03 & 10.89 & 41.99 \\
\hline & 24 & 21.65 & 18.99 & 2.65 & 5.54 & 11.42 & 41.54 \\
\hline & 25 & 20.89 & 19.3 & 2.12 & 5.17 & 10.23 & 42.25 \\
\hline & 26 & 22.01 & 18.79 & 2.78 & 6.33 & 11.38 & 42.85 \\
\hline & 27 & 20.77 & 19.57 & 2.43 & 5.83 & 10.54 & 41.33 \\
\hline
\end{tabular}

$*$ P penetration rate, $\sigma c$ Uniaxial compressive strength, $\sigma$ shear strength, Ts Tensile strength, PLT point load strength, I.S impact strength.

Specific energy (SE) is; a significant indicator, used to evaluate the performance of drilling operation. It is directly compatible with cost/meter, as it refers to the amount of energy required to penetrate/percolate rock. Specific energy (SE) could be employed as a tool to measure the bit function (e.g., bit behaviour in cutting stones) and strength characterization of rocks (Murry and Cunningham, 1955). The energy (e.g., expanded from a source through the drill bit) required for drilling/removing a unit volume of rock is a definition of specific energy (SE). It depends mainly on other drilling parameters such as: thrust (WOB), drilling speed (RPM), and penetration rate $(\mathrm{P})$, and strength properties of rocks. Teale's formula is used to estimate the specific energy (SE), as per Equation 1 below:

$$
S E=\frac{F}{A}+2 \pi \frac{N T}{A P}, \quad N . \mathrm{cm} / \mathrm{cm}^{3}
$$

$\mathrm{F}=$ thrust $(\mathrm{WOB}), \mathrm{N}$

A: cross-sectional area of drill hole $\left(\mathrm{A}=\pi \mathrm{r}^{2}=\pi(2.5)^{2}=20\right.$ $\left.\mathrm{cm}^{2}\right), \mathrm{cm}^{2}$,

$\mathrm{N}$ : rotational (drilling) speed $(\mathrm{N}=380 \mathrm{rpm}), \mathrm{RPM}$,

T: Torque (e.g. $\mathrm{T}=100 \mathrm{~N} . \mathrm{cm})$, and

$P$ : Penetration rate $(\mathrm{cm} / \mathrm{min})$.

By applying Teale's formula; (e.g., equation (1)), to estimate the value of specific energy consumed to drill each rock. The relationship between penetration rate $(\mathrm{p})$ and thrust $(\mathrm{F})$ is given in Equation $((2)$ below. Final results of calculated specific energy (SE) are listed below in Table (4).

$$
S E=0.05\left(F+\frac{240}{P}\right)
$$

Where:

Table 4: Estimated specific energy (SE) at various values of thrust $(\mathrm{F})$ and rate of penetration $(\mathrm{P})$ for natural and artificial rocks

\begin{tabular}{|l|l|l|l|}
\hline Rock Types & F, KN & P, mm/min & SE, MPa \\
\hline Natural & 314 & 2.87 & 19.88 \\
\hline Marble 1 & 315 & 4.99 & 18.15 \\
\hline Marble 2 & & & \\
\hline
\end{tabular}




\begin{tabular}{|l|l|l|l|}
\hline Limestone1 & 418 & 13.25 & 21.81 \\
\hline Limestone 2 & 509 & 12.45 & 26.41 \\
\hline Sandstone & 390 & 35.86 & 19.83 \\
\hline Basalt & 455 & 1.75 & 29.61 \\
\hline Dolomite & 380 & 2.55 & 23.71 \\
\hline Artificial & \multicolumn{3}{|l}{} \\
\hline Cement + Sand & 240 & 33.25 & 12.36 \\
\hline Lime + Dolom & 157 & 28.99 & 8.26 \\
\hline Dolom + Basalt & 180 & 26.45 & 9.45 \\
\hline Basalt + Lime & 235 & 20.55 & 12.33 \\
\hline Lime + Dolom + Basalt & 240 & 21.33 & 12.56 \\
\hline
\end{tabular}

\section{RESULTS AND DISCUSSIONS}

The least square regression method was adopted to identify the rock penetration rate according to its strength property. Two functions were examined and plotted here, logarithmic and exponential, during the regression analysis. The equation which gives the best correlation coefficient $\left(\mathrm{R}^{2}\right)$ is then selected. Table (6) displayed the correlation coefficients obtained from regression analysis. As well,
Figure $4 \mathrm{a}$ to $4 \mathrm{f}$ presents the exponential relationship between penetration rate and strength properties of the tested rocks. It is clearly that, uniaxial compressive strength and tensile strength give high correlation coefficient $\left(R^{2} \geq 0.75\right)$ for both exponential and logarithmic functions, with the penetration rate. While the relationship between Barazilian tensile strength and rate of penetration shows correlation coefficient of $\mathrm{R}^{2} \geq 0.7$.

Table 6: Regression analysis for rock samples

\begin{tabular}{|c|c|c|c|c|}
\hline \multirow{3}{*}{$\begin{array}{c}\text { *Strength } \\
\text { property }\end{array}$} & \multicolumn{2}{|l|}{ Penetration Rate (PR) } & \multicolumn{2}{|l|}{ Specific Energy (SE) } \\
\hline & Exponential & Logarithmic & Exponential & Logarithmic \\
\hline & $\begin{array}{c}\mathrm{PR}=0.124\left(\sigma_{c}\right)^{2}- \\
6.545\left(\sigma_{c}\right)+111.2 \\
\mathrm{R}^{2}=0.813\end{array}$ & $\begin{array}{l}\mathrm{PR}=-26.6 \ln \left(\sigma_{c}\right)+117.9 \\
\mathrm{R}^{2}=0.754\end{array}$ & $\begin{array}{llr}\mathrm{SE}= & -0.000\left(\sigma_{c}\right)^{2} & + \\
4.387\left(\sigma_{c}\right) & - & 23.66 \\
\mathrm{R}^{2}=0.837 & & \end{array}$ & $\begin{array}{l}\mathrm{SE}=72.85 \ln \left(\sigma_{c}\right)-151.2 \\
\mathrm{R}^{2}=0.806\end{array}$ \\
\hline$\sigma_{\tau}$ & $\begin{array}{c}\mathrm{PR}=0.014(B z)^{2}- \\
0.732(B z)+12.49 \\
\mathrm{R}^{2}=0.724\end{array}$ & $\begin{array}{l}\mathrm{PR}=-2.78 \ln (B z)+13.00 \\
\mathrm{R}^{2}=0.657\end{array}$ & $\begin{array}{ccc}\mathrm{SE}= & 0.001(\mathrm{v})^{2} & + \\
0.487(B z) & - & 2.653 \\
\mathrm{R}^{2}= & 0.864\end{array}$ & $\begin{array}{c}\mathrm{SE}=8.913 \ln (B z)-18.38 \\
\mathrm{R}^{2}=0.827\end{array}$ \\
\hline Ts & $\begin{array}{l}\mathrm{PR}=0.03(\mathrm{Ts})^{2}- \\
1.610(\mathrm{Ts})+27.71 \\
\mathrm{R}^{2}=0.847\end{array}$ & $\begin{array}{l}P R=-6.81 \ln (T s))+29.78 \\
R^{2}=0.814\end{array}$ & \begin{tabular}{l}
$\mathrm{SE}=\quad 0.011(\mathrm{Ts})^{2}$ \\
$0.638(\mathrm{Ts}) \quad-\quad 2.4$ \\
\multicolumn{3}{c}{$\mathrm{R}^{2}=0.807$}
\end{tabular} & $\begin{array}{c}\mathrm{SE}=17.43 \ln (\mathrm{Ts})-35.70 \\
\mathrm{R}^{2}=0.762\end{array}$ \\
\hline PLS & $\begin{array}{l}\mathrm{PR}=0.056(\mathrm{PLS})^{2}- \\
3.170(\mathrm{PLS})+60.27 \\
\mathrm{R}^{2}=0.717\end{array}$ & $\begin{array}{l}\mathrm{PR}=-14.2 \ln (\mathrm{PLS})+65.13 \\
\mathrm{R}^{2}=0.686\end{array}$ & $\begin{array}{l}\mathrm{SE}=\quad 0.432(\mathrm{PLS})^{2} \\
+0.976(\mathrm{PLS}) \quad-\quad 2.442 \\
\mathrm{R}^{2}=0.9\end{array}$ & $\begin{array}{l}\mathrm{SE}=41.22 \ln (\mathrm{PLS}) \\
85.04 \\
\quad \mathrm{R}^{2}=0.827\end{array}$ \\
\hline I.S. & $\begin{array}{l}\mathrm{PR}=\quad 0.054(\mathrm{Is})^{2}- \\
3.059 \text { (Is) }+{ }^{2} 88.77 \\
\mathrm{R}^{2}=0.696\end{array}$ & $\begin{array}{l}\mathrm{PR}=-13.6 \ln (\mathrm{Is})+93.47 \\
\mathrm{R}^{2}=0.670\end{array}$ & $\begin{array}{l}\mathrm{SE}=0.030(\mathrm{Is})^{2}+1.259(\mathrm{Is}) \\
+\quad 26.88 \\
\mathrm{R}^{2}=0.806\end{array}$ & $\begin{array}{l}\mathrm{SE}=36.75 \ln (\mathrm{Is})-42.11 \\
\mathrm{R}^{2}=0.737\end{array}$ \\
\hline
\end{tabular}

${ }^{*} \sigma_{\mathrm{S}}$ Uniaxial compressive strength, $\sigma_{\tau}$ shear strength, Ts Tensile strength, PLT point load strength, I.S impact strength. 


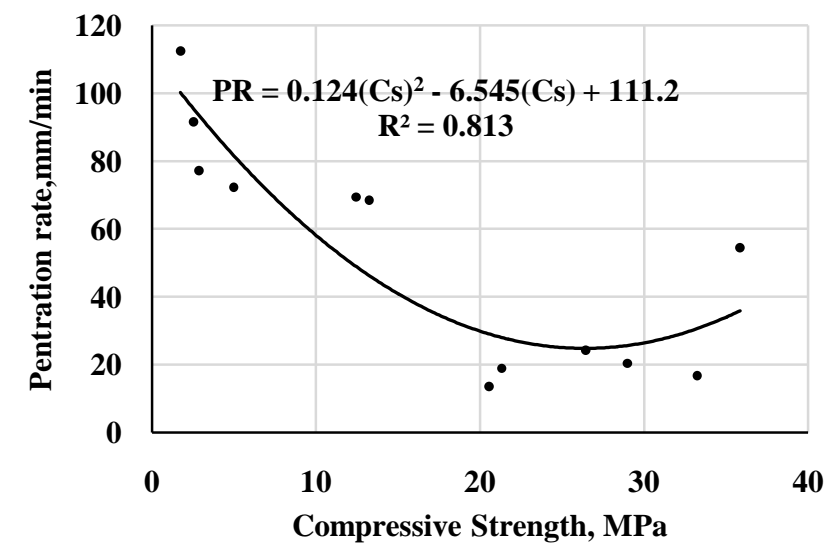

4.a

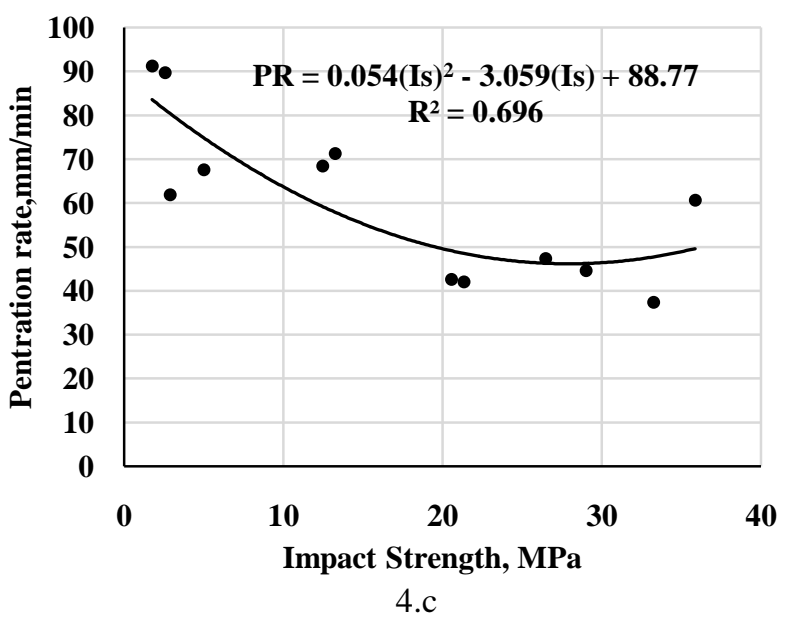

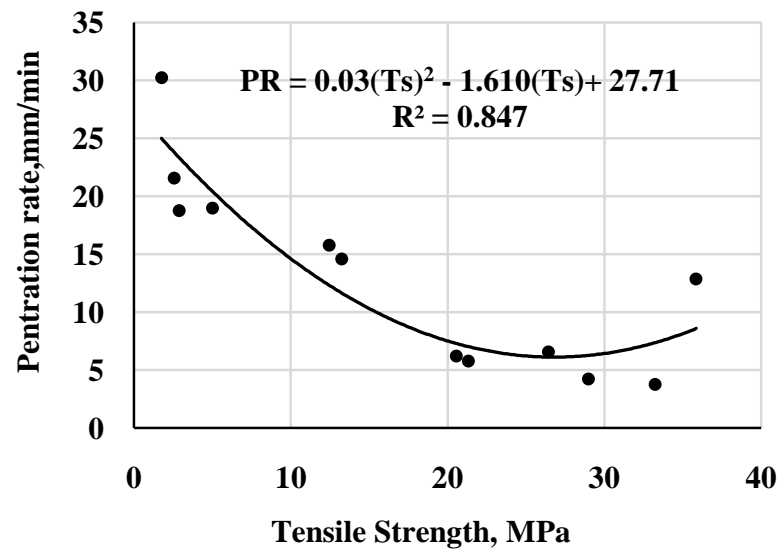

4.b

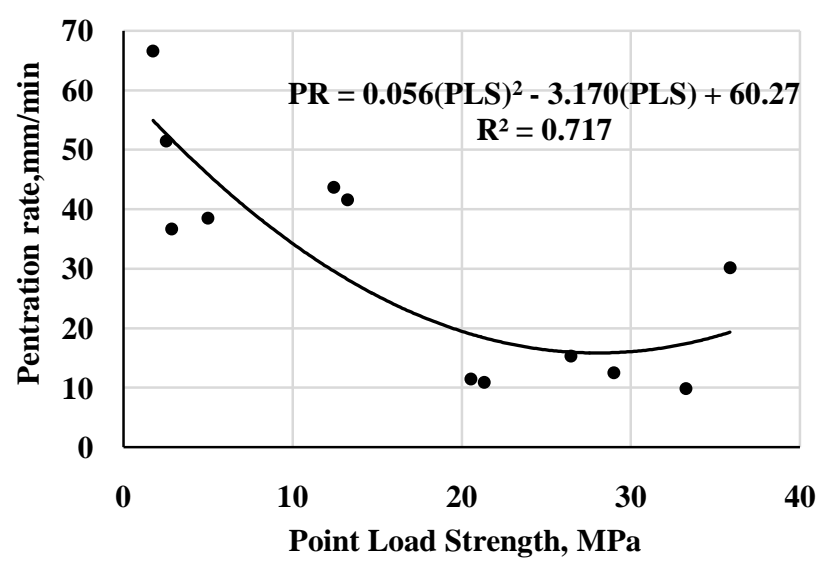

4.d

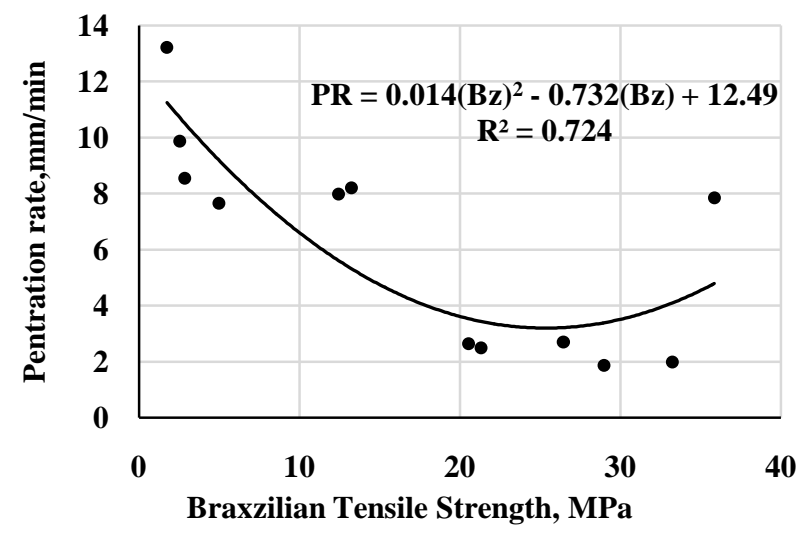

4.f

Fig 4a to 4f: The exponential relationship between penetration rate and sample properties 
The logarithmic relationship between penetration rates and strength properties of rocks is depicted in Figure $5 \mathrm{a}$ to $5 \mathrm{f}$ below.

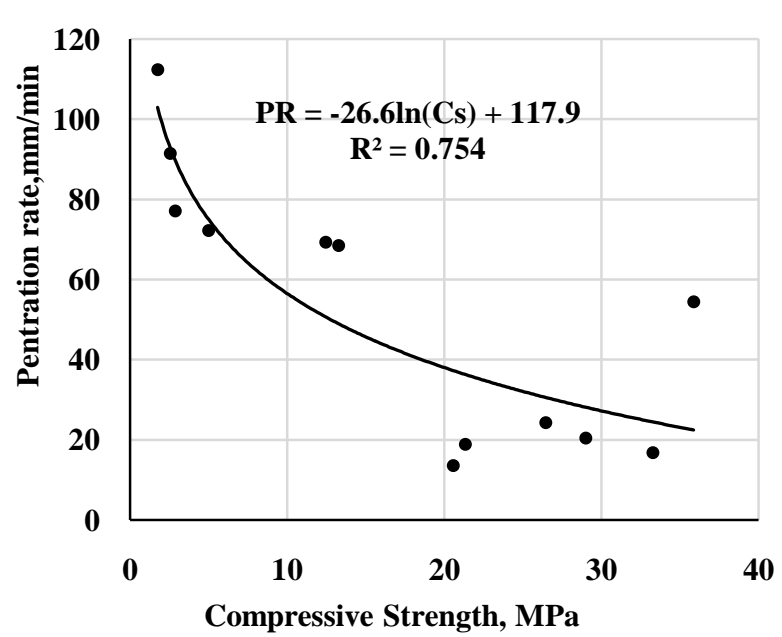

$5 a$

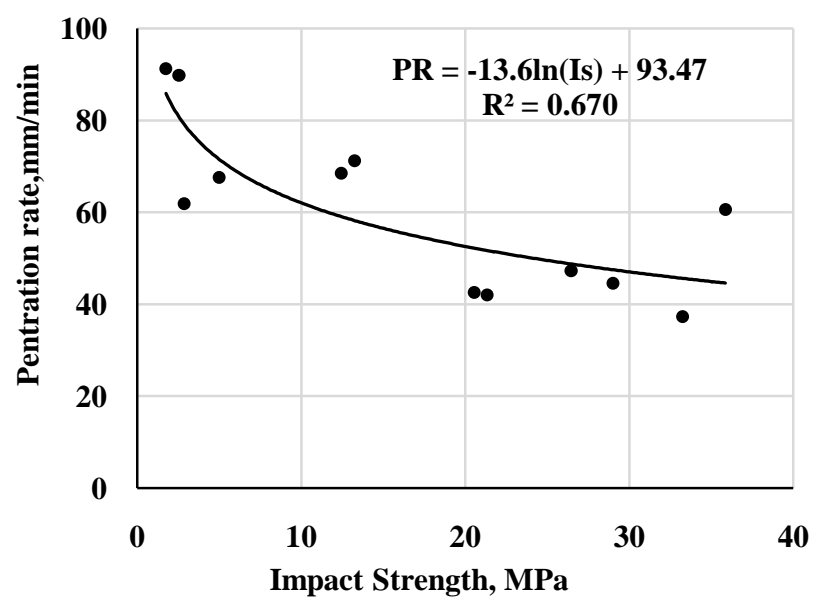

$5 \mathrm{c}$

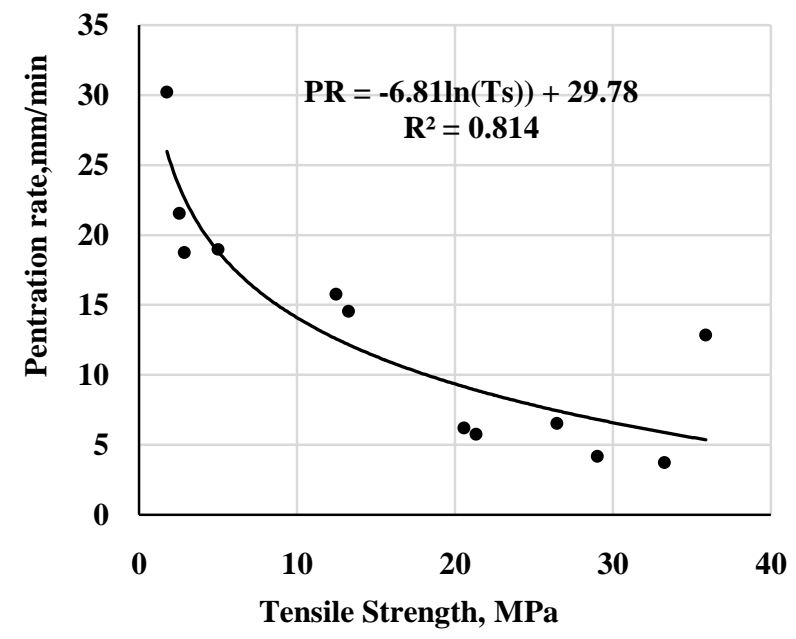

$5 b$

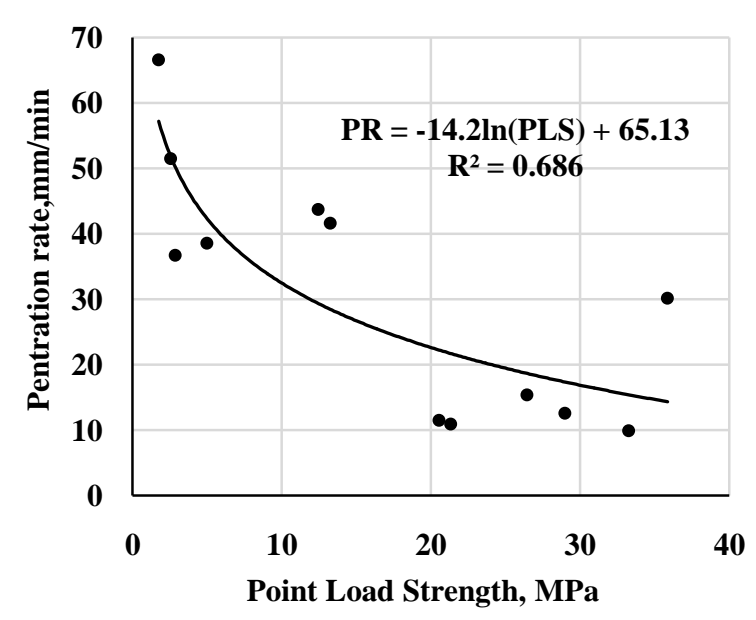

$5 d$

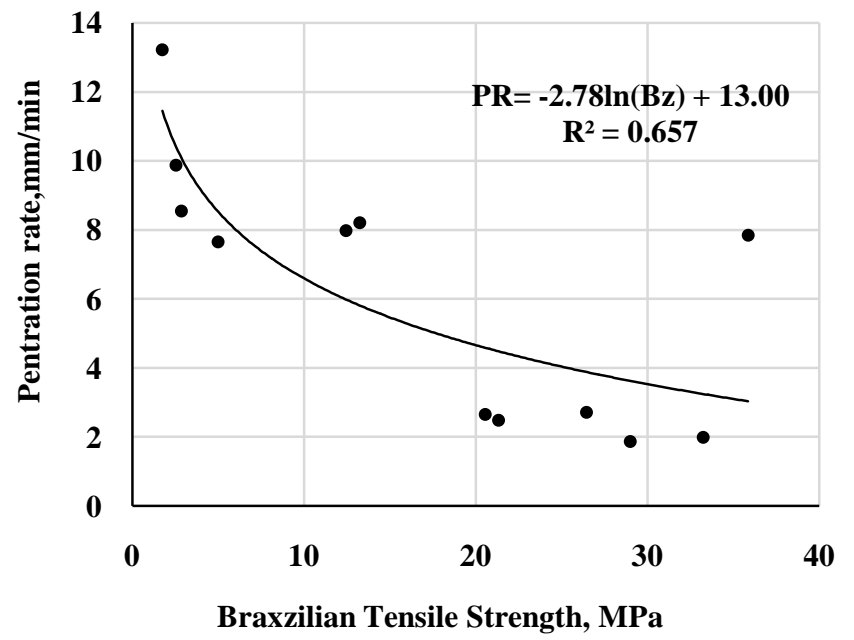

$5 f$

Fig 5a to 5f: The logarithmic relationship between penetration rate and sample properties 
The exponential relationship between specific energy (SE) and strength properties of rocks is shown in Figure $6 \mathrm{a}$ to $6 \mathrm{f}$ below. The regression analysis shows strong coefficient of correlation between strength properties of rocks and specific energy (SE).

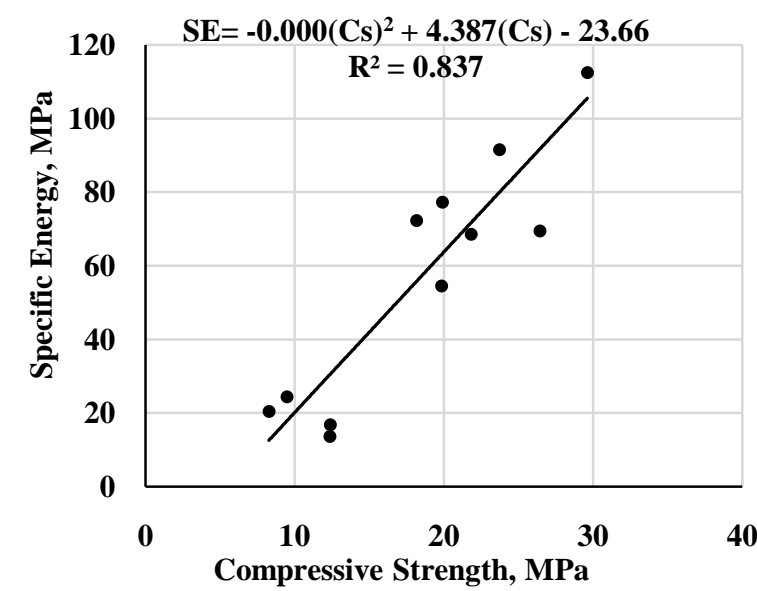

$6 \mathrm{a}$

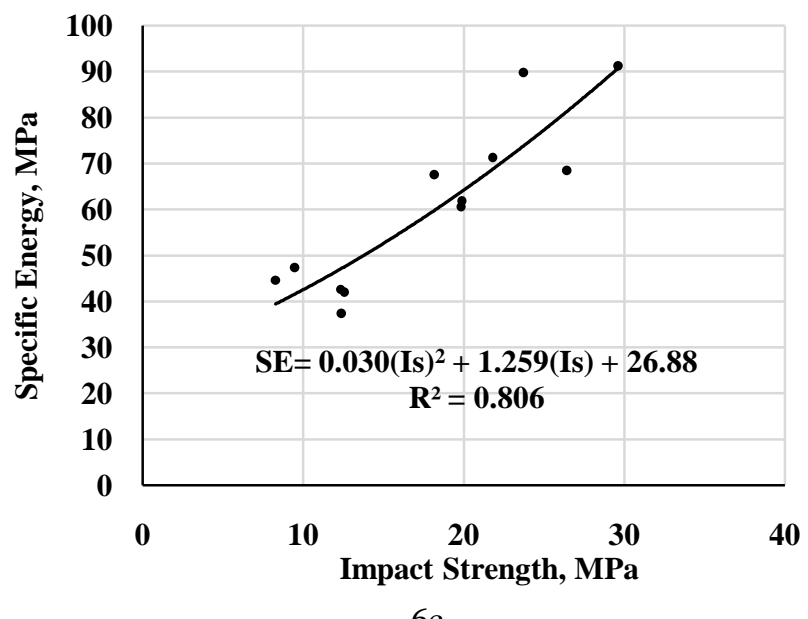

$6 c$

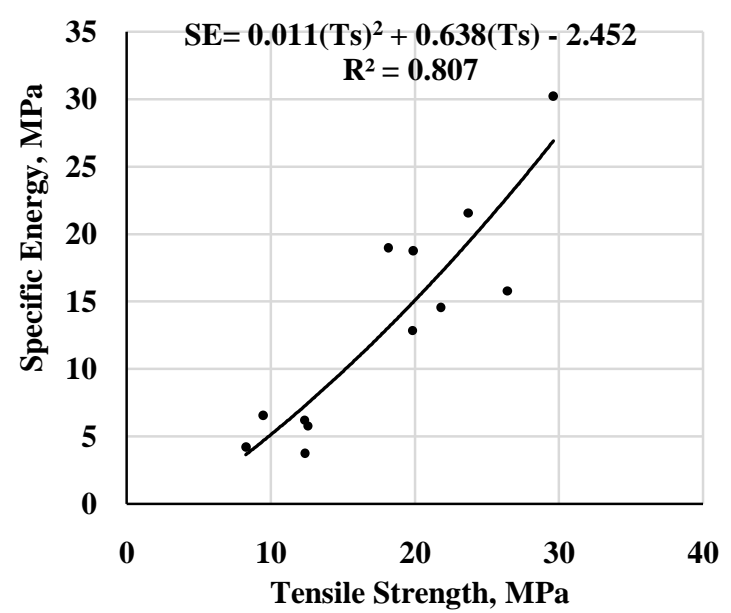

$6 \mathrm{~b}$

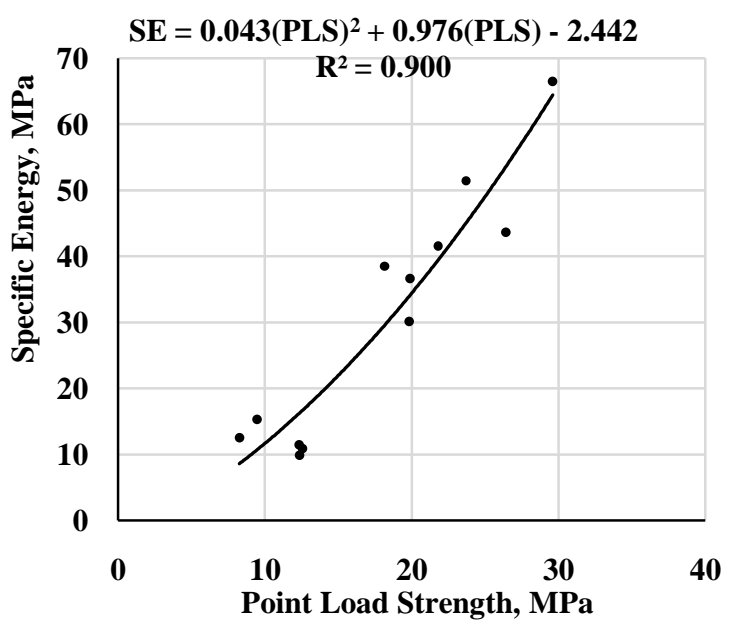

$6 \mathrm{~d}$

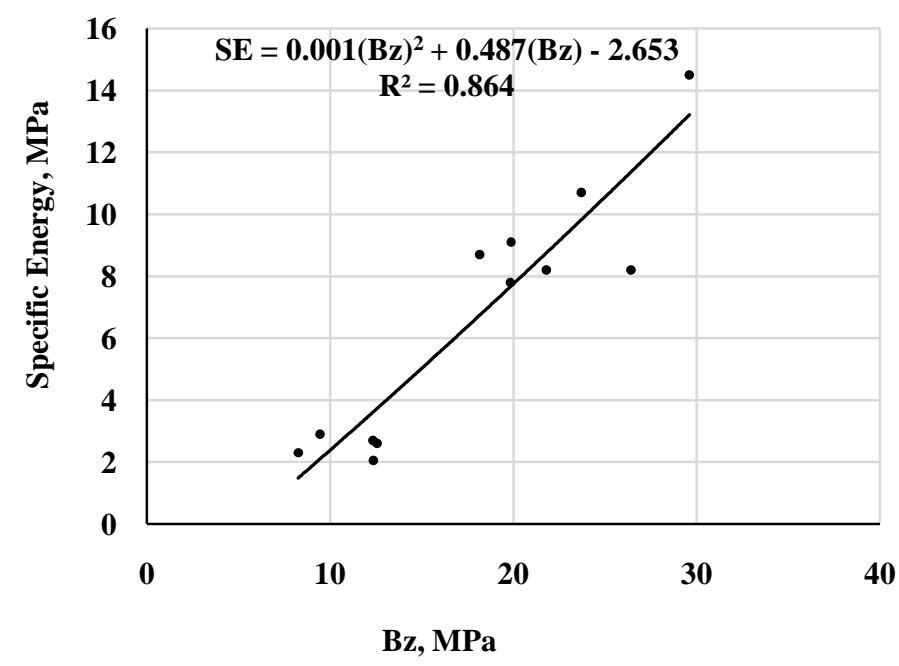

$6 f$

Fig 6a to 6f: The exponential relationship between specific energy (SE) and strength properties of rocks 
Figure 7a to 7 fdepicts the logarithmic relationship between specific energy (SE) and characteristics strength of the tested rocks.

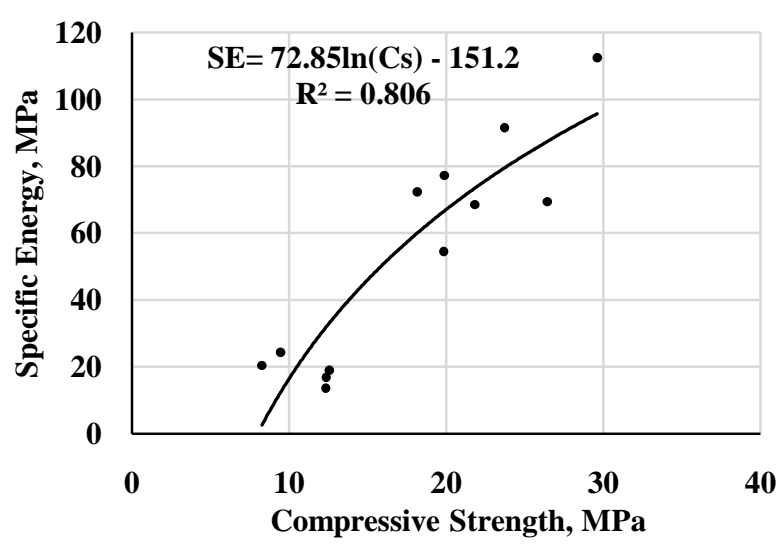

$7 \mathrm{a}$

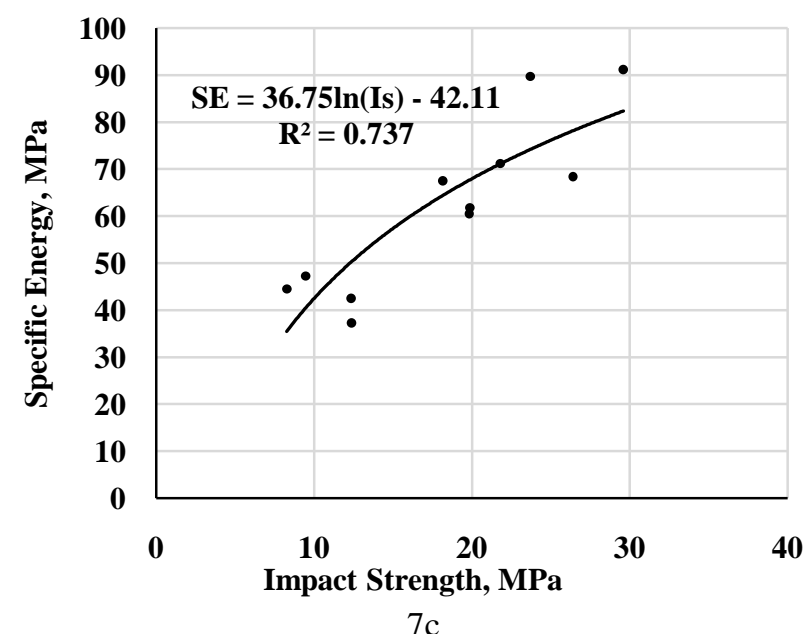

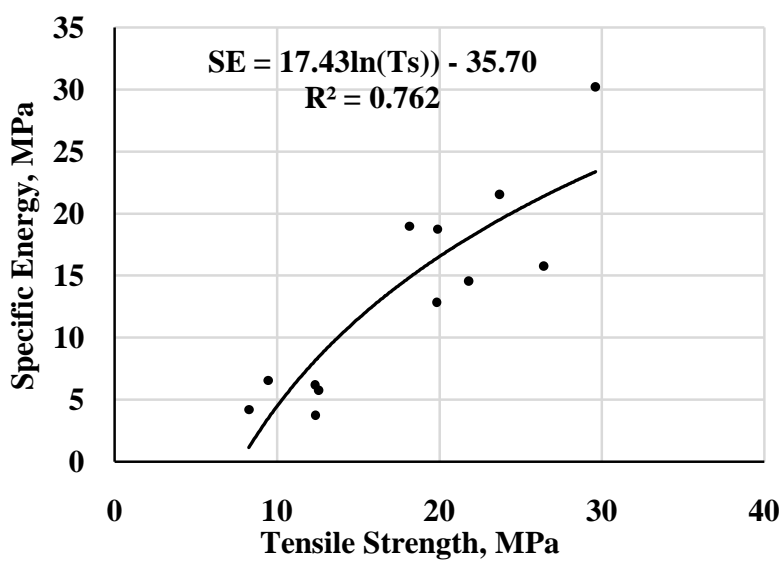

$7 b$

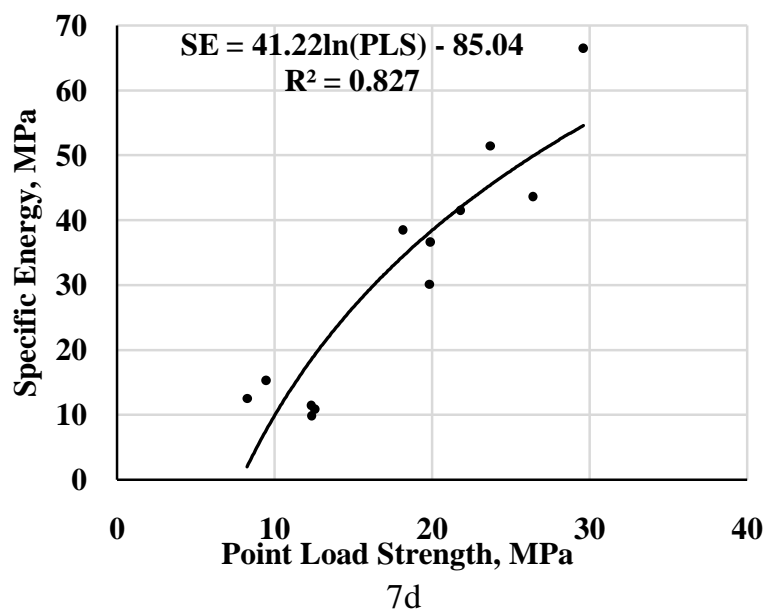

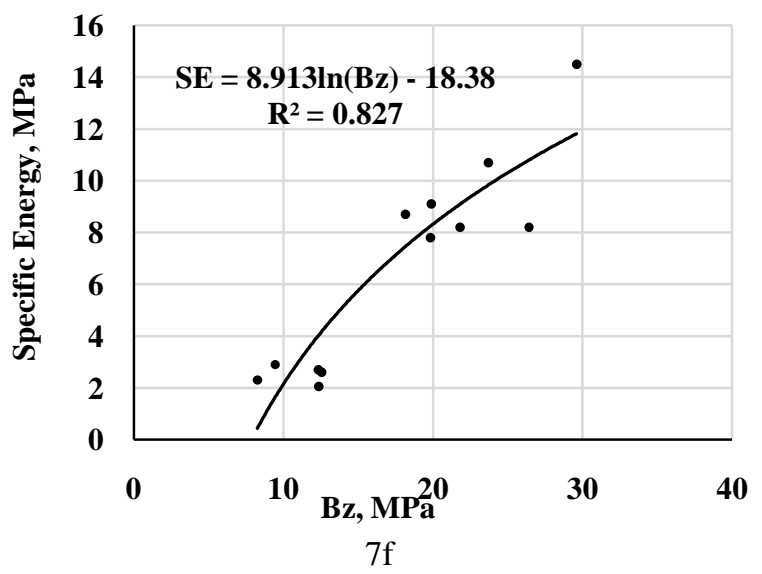

Fig 7a to 7f: The logarithmic relationship between specific energy (SE) and strength properties of rocks

\section{CONCLUSION}

Rock strength properties are one of the most significant parameters influencing the rock drillability. Prediction of the penetration rate is necessary for preliminary estimating the cost and planning of the projects. Regression analysis has been conducted; using natural and artificial stones in this study, and relationships between penetration rate, specific energy and strength characteristics of rocks have been established. Uniaxial compressive strength, Barazilian tensile strength, shear strength, point load strength and impact strength are found to be dominant rock properties affecting the penetration rate of rotary drills. The analysis revealed strong correlation coefficients between penetration 
rates, specific energy and strength properties of rocks. The derived prediction equations could be adopted to estimate/predict the penetration rates as well the required specific energy. However, further analysis has to be carried out to confirm their validity for other different rock types.

\section{REFERENCES}

[1] Adamson W. R., "Correlation of model excavating machine performance with rock properties and rotary drilling performance data" M.Sc. Thesis, Univ. of Queensland, p. 124, (1984).

[2] Clark G. B., (1979). Principal of rock drilling. Colorado School of Mines.

[3] Fish, B. G. The basic variables in rotary drilling'. Mine \& Quarry Engineering, 1968, 27, pp. 74-81.

[4] ISRM (1981). Rock characterization testing and monitoring ISRM suggested methods, suggested methods for determining hardness and abrasiveness of rocks, 3: 101-103.

[5] Kahraman S., (1999). Rotary and percussive drilling prediction using regression analysis. Int. J. Rock. Mech. Min. Sci., 36: 981-989.

[6] Kahraman S, Balcı C, Yazıcı S, Bilgin N (2000). Prediction of the penetration rate of rotary blast hole drills using a new drillability index. Int. J. Rock Mech. Min. Sci., 37: 729-743.

[7] Kahraman S., "Correlation of TBM and drilling machine performances with rock brittleness", Int. J. Rock Mech. Min. Sci., 65 (2002): 269-283.

[8] Kahraman S, Bilgin N, Feridunoğlu C (2003). Dominant rock properties affecting the penetration rate of percussive drills. Int. J. Rock. Mech. Min. Sci., 40: 711-723.

[9] Kaipuz. C. Pasamehmetoglu. A.C. Dincer. T. \&Muftuoglu. Y. 1990 Diillabihty studies on the rotary blast hole drilling ot lignite overburden series. Int. J. Surfine Min. Reel. 4- 89-93.

[10] Morris.R.J.1969. Rock drillability related to a roller cone bit. SPE 2389: 79-83.

[11] Murry, S, A., and Cunningham, A. R., "Effect of mud column pressure on drilling rates", Vol. 204, Pp.196204, Canada, 1955.

[12] Pandey. A. K. Jam. A. K. \& Singh. D. P. 1991. An investigation into rock drilling, hit J Surfine Mm. Ret luintition 5"139-141.

[13] Paone J., Bruce, W.E., and Virciglio, P.R., 1966. Drillability studies - statistical regression analysis of diamond drilling, US Bureau of Mines RI 6880.

[14] Paone J., Madson, D. and Bruce, W.E., 1969. Drillability studies-laboratory percussive drilling, US Bureau of Mines RI 7300.

[15] Reddish. D.J. \&Yasar. E. 1996. A new portable rock strength index lest based on specific energy of drilling Int. J. Ruck Meih. Min. Sei. 33 (5): 543-548.

[16] Teale, R. 1964. The concept of Specific Energy in Rock Drilling. Int. J. Rock Mech. Mining Sci Vol.2, pp. 57-73.

[17] Warren. TM. 1981. Drilling model for soft-formation bits. J. Petrol. Teihnol. 33: 963-969. 